\title{
Palestinian membership puts UN projects at risk
}

\section{Science and culture agency loses US funding, and other bodies could follow.}

\section{BY DANIEL CRESSEY AND DECLAN BUTLER}

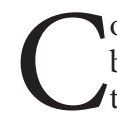

oncern is growing that United Nations bodies could face budget crises after the UN agency responsible for science suffered a drastic cut in contributions following a vote in which it admitted the Palestinian Authority as a member.

The vote on 31 October by the UN Educational, Scientific and Cultural Organization (UNESCO), based in Paris, caused the United States to pull its $22 \%$ share of the agency's budget — some US $\$ 80$ million a year. US law prevents the nation from funding any UN body that grants full membership to any organization or group that is not an internationally recognized state.

Following the vote, Irina Bokova, UNESCO's director-general, said that she was "concerned by the potential challenges that may arise to the universality and financial stability of the Organization". Other countries, such as Canada and Israel, have followed the United States in withdrawing funding; the cuts will put pressure on UNESCO-funded science and education projects.

The US Department of State has warned of a potential 'cascade' effect. As part of continuing attempts to win recognition as an independent state, the Palestinian Authority is reportedly set to apply to join other UN agencies, including the World Health Organization (WHO) in Geneva, Switzerland; the International Atomic Energy Agency (IAEA) in Vienna; and the Food and Agriculture Organization (FAO) in Rome. All of these groups get around one-fifth of their direct funding from the United States, and would lose it if they admitted a Palestinian state.
At UNESCO, 107 nations voted for Palestinian membership and only 14 against, with 52 abstentions. A similar selection of states are members of other UN bodies, so further Palestinian applications have a good chance of success. However, other bodies have different systems for granting membership.

UNESCO funds and runs many international science projects, including a tsunami-warning system in the Indian Ocean, put in place after the 2004 disaster. It also runs science-policy

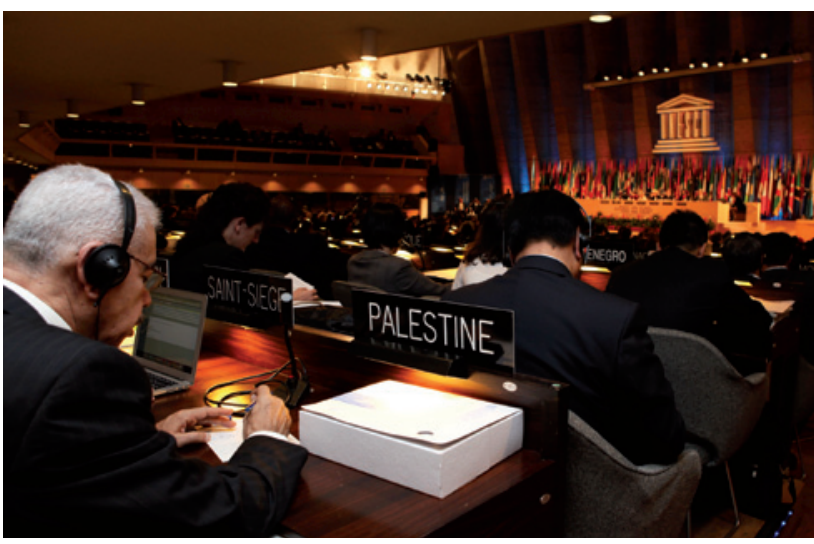

UN agencies risk their budgets by voting for Palestinian membership. hagen and a member of the Danish National Commission for UNESCO, says that UNESCO programmes are already "systematically" short of funding. "With a very significant reduction of the budget I fear that significant activities will have to be discontinued entirely and some very hard choices will have to be made," he says.

As Nature went to press, the FAO, the WHO and the IAEA said that they had not received applications from the Palestinian Authority. The FAO and the IAEA would not comment on whether they have contingency plans to deal with a potential loss of US funding. A spokesperson for the WHO said that because it has not yet received a membership request, the organization has not reached the point of considering revised funding plans.

Kelley Lee, director of global health at Simon Fraser University in Burnaby, Canada, said that other countries might make up any shortfall in funding if the UNESCO situation was repeated at the WHO. "China is an obvious country to step in," she says.

But a Palestinian membership attempt could be particularly prob- and education programmes. "The present cuts will seriously reduce the good work currently in hand," says Peter Fensham, emeritus professor of science education at Monash University in Melbourne, Australia, who has worked with UNESCO. He adds, "I also remember how handicapped UNESCO's very good work in science education was when the United States and United Kingdom cut off funding in the Reagan and Thatcher eras."

Jens Jørgen Gaardhøje, a physicist at the Niels Bohr Institute at the University of Copenlematic at the WHO. The agency is preoccupied with a huge internal reform driven by its director-general, Margaret Chan (see Nature 473, 430-431;2011), so its members may resist Palestinian overtures. "Overall, my feeling is that it is unlikely to happen given the current and indeed long-standing financial austerity within the organization and Margaret Chan's focus on protecting the organization's financial and political standing," says Lee. "Palestinian membership poses higher risks than I think the organization can bear at present." -

\section{MORE
ONLINE}

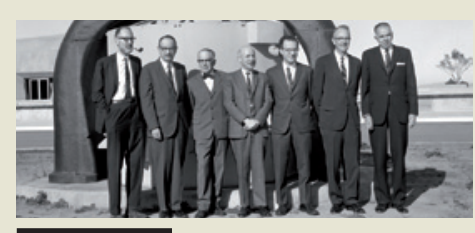

TOP STORY

Nobel laureates age like a fine wine go.nature.com/vwoidq

\section{MORE NEWS}

- Tyrannosaurs were power-walkers go.nature.com/rvjesw

- Russia takes aim at Phobos go.nature. com/6yapyx

- Nanoparticle solar cells offer fresh promise for printable photo voltaics go.nature.com/ohv2eq

\section{ON THE BLOG}

Bat flight evolved from a flutter to get at insects, rather a glide go.nature.com/ xgodno

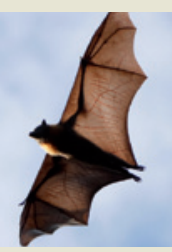

